\title{
A Lâmpada e Sua Chama de frogo como Símbolo da Enfermagem
}

nümeros povos culuuam ou veneram o fogo como demento indispensável à sua sobrevivência, mas é principalmente no clomínio do sobrenatural que o fogo exerceu fortennente o seu poder:

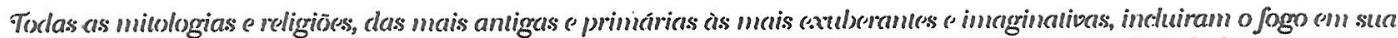
liturgia, invos:ando-o, exibindes-o ou a ele dedicando sacurficioss, como mediador entre o homem e a divindade ou como elemento purificador. Alluilas vezess é identificado como a própria forcecr divina.

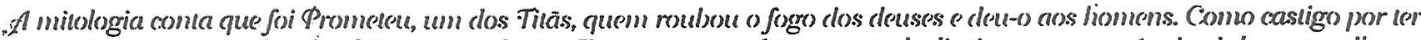

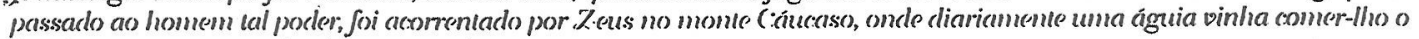
figado que se vecrompunha duramee a noile.

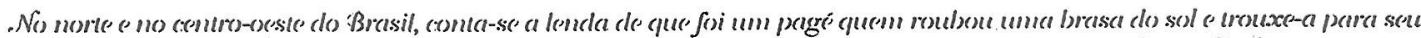

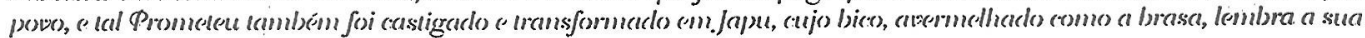
mesamorfose.

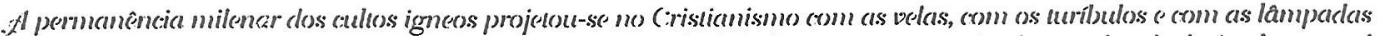

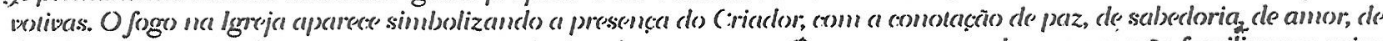

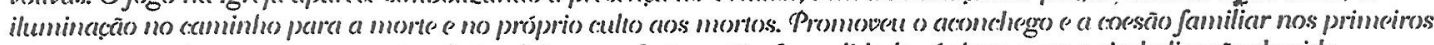

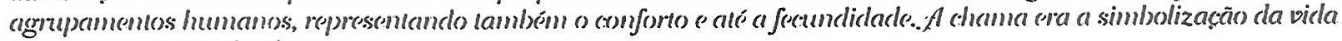
Inamenare mesmes da alma.

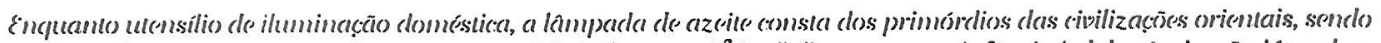

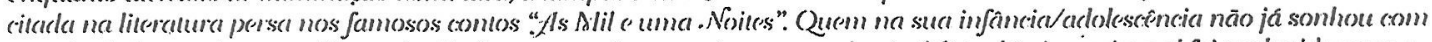

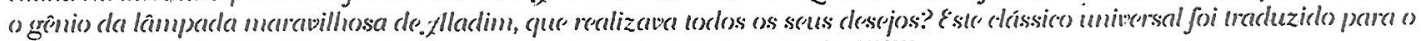

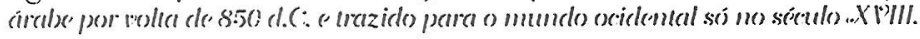

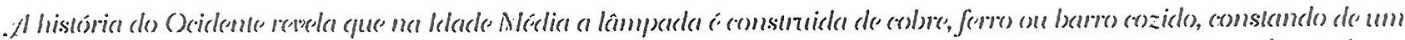

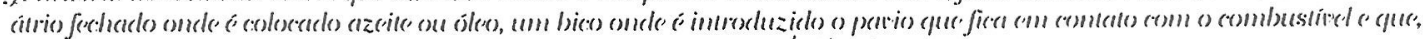

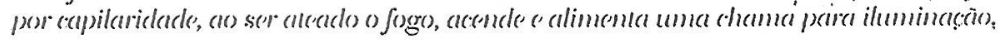

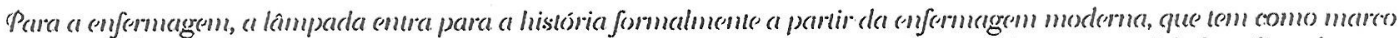

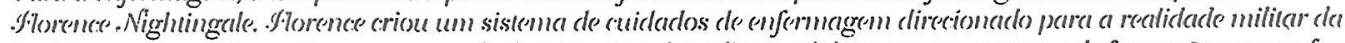

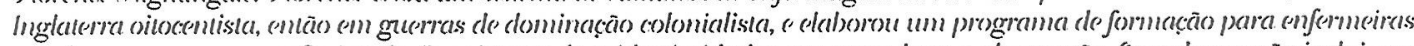

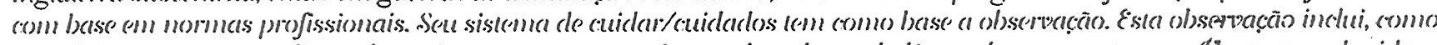

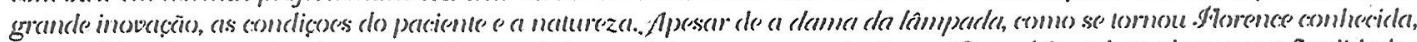

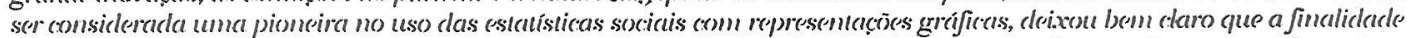

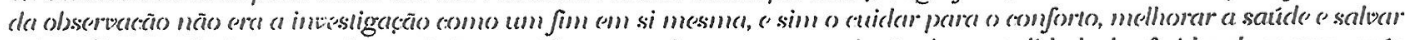

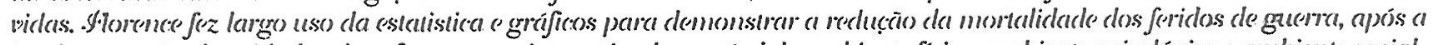

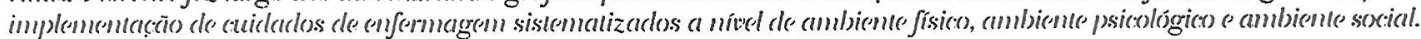

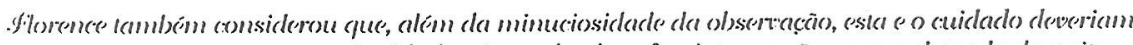

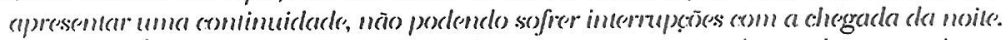

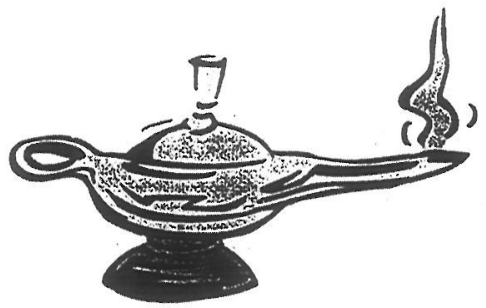

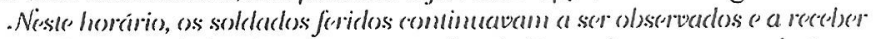

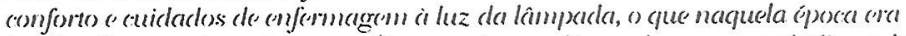

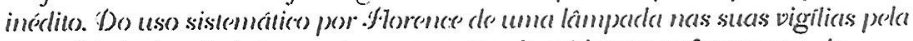

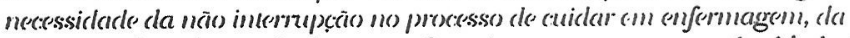

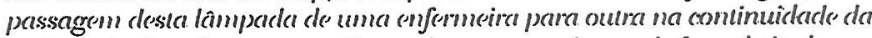

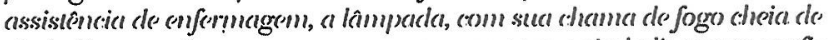

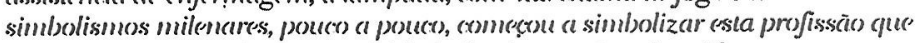

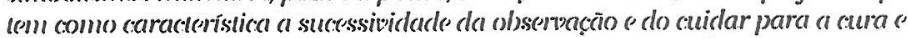
para a vick.

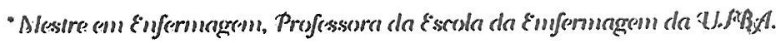

